\title{
ANALISIS KADAR TANIN DALAM EKSTRAK DAUN MIMBA (AZADIRACHTA INDICA A. JUSS) DENGAN PELARUT AIR DAN ETANOL
}

\section{Analysis of Tannin Levels in Neem (Azadirachta Indica A. Juss) Leaves Extracts with Water and Ethanol Solvents}

\author{
*Mihra, Minarni Rama Jura, dan Purnama Ningsih \\ Pendidikan Kimia/FKIP - Universitas Tadulako, Palu - Indonesia 94118 \\ Received 30 August 2018, Revised 28 September 2018, Accepted 04 November 2018
}

\begin{abstract}
Neem plant is a widely used in agriculture as green fertilizer, pesticides and insecticides. People usually use the leaves as for lowering blood sugar, skin diseases, preventing infection, and reducing itching. This study aims to identify and determine tannins levels containing in neem leaves extracts. This study applied extraction by maceration method using 2 different solvents, water and ethanol. Tannin is a metabolite secondary compound belong to phenolic compound groups which oxidized easily by strong oxidization agent (potassium permanganate) so then its determination utilized permanganate method (Lowenthal-Procter). The results showed that neem leaves in $250 \mathrm{~mL}$ water solvent contains $0.55 \%$ of tannin, while in $250 \mathrm{~mL}$ ethanol solvent and concentration of $96 \%$ contains $0.27 \%$ of tannin.
\end{abstract}

Keywords: Neem leaves, tannin, permanganometry method

\section{Pendahuluan}

Indonesia sebagai negara tropis mempunyai keragaman flora dan fauna yang sangat berlimpah. Tanahnya yang subur dan iklim yang menunjang memiliki keragaman pohon dan tanaman hias (floriculture) yang cukup besar, namun keragaman tersebut belum dimanfaatkan dengan optimal dan belum ditangani dengan maksimal (Timothy, dkk., 2011).

Banyak jenis tanaman yang dapat tumbuh di Indonesia yang sebagian besar dapat digunakan sebagai sumber bahan obat alam dan telah banyak digunakan oleh masyarakat secara turun temurun untuk keperluan pengobatan guna mengatasi masalah kesehatan. Obat tradisional tersebut perlu diteliti dan dikembangkan sehingga dapat bermanfaat secara optimal untuk peningkatan kesehatan masyarakat (Desinta, 2015).

Salah satu tumbuhan di Indonesia yang sangat banyak mempunyai manfaat dalam bidang kesehatan yaitu tanaman mimba (azadirachta indica A. Juss). Tanaman mimba banyak tumbuh di kelurahan Tondo Kecamatan Mantikulore kota Palu Provinsi Sulawesi Tengah. Pohon ini mempunyai berbagai manfaat untuk pertanian dan kesehatan. Tanaman mimba, khususnya pada daun dan bijinya dapat digunakan sebagai pupuk hijau, pestisida, dan insektisida. Pestisida alami yang terbuat dari biji mimba merupakan alternatif pestisida kimia bagi petani (Agus \& Rahayu, 2004).

Daun mimba digunakan untuk penambah nafsu makan, untuk menanggulangi disentri, borok, malaria, dan antibakteri. Tangkai dan ranting mimba mengandung senyawa triterpen dan tetraterpen

\section{${ }^{*}$ correspondence:}

\section{Mihra}

Program Studi Pendidikan Kimia, Fakultas Keguruan dan IImu Pendidikan, Universitas Tadulako e-mail:mihrausman@gmail.com

Published by Universitas Tadulako 2018 (limonoid, protolimonoid dan kelompok gedunin). Minyak biji terdapat nimbolin a dan b, nimbin, dan gedunin. Tanin dan minyak atsiri terdapat pada kulit kayu dan daun (Jesudoss, dkk., 2014). Daun mimba mengandung senyawa metabolit sekunder yaitu minyak atsiri dan tanin sehingga diduga senyawa aktif tersebut dapat digunakan sebagai antibakteri, misalnya sebagai pengawet alami karena jumlahnya melimpah, tanaman ini juga sangat mudah didapatkan (Ummah, 2010).

Tanin merupakan senyawa aktif metabolit sekunder yang diketahui mempunyai beberapa khasiat yaitu sebagai astrigen, antidiare, antibakteri, dan antioksidan (Malangngi, dkk., 2012). Tanin dapat digunakan sebagai antibakteri karena mempunyai gugus fenol, sehingga tanin mempunyai sifat-sifat seperti alkohol yaitu bersifat antiseptik yang dapat digunakan sebagai komponen antimikroba. (Rishika \& Sharma, 2012) menyebutkan karena adanya senyawa tanin yang terkandung dalam ekstrak daun jambu biji dapat menghambat aktivitas pertumbuhan antimikrobia terhadap organisme (sarcina lu tea dan staphylococcus aureus dan mycobacterium Phlei).

Hasil penelitian Handayani, dkk., (2012) menunjukkan bahwa serbuk daun mimba pada fraksi etil asetat memiliki fraksi teraktif antibakteri terhadap S.epidermidis, B.cereus, dan S. flexneri. Senyawa aktif yang diduga memiliki aktivitas antibakteri adalah flavonoid, tanin dan saponin, dan belum ada penelitian tentang apakah senyawa tanin dalam daun mimba dapat digunakan sebagai antibakteri (Jayaraman, dkk., 2014). Daun mimba yang digunakan dalam penelitian ini adalah daun yang masih muda dan segar karena dimungkinkan senyawa tanin banyak terdapat dalam daun muda. Menurut (Lailis, 2010) daun muda lebih rentan dari hama dari pada daun yang tua karena kandungan senyawa tanin pada daun muda lebih banyak dari pada daun tua, hal ini dikarenakan pada daun tua sebagian telah 
mengalami oksidasi, sehingga dalam penelitian ini digunakan daun mimba yang masih muda dan segar.

Pemisahan senyawa tanin salah satunya dipengaruhi oleh pelarut, sehingga dalam penelitian ini digunakan pelarut air dan etanol, pelarut yang digunakan adalah pelarut yang bersifat polar karena tanin merupakan senyawa polar. Pemilihan metode aktivitas tanin yang diekstrak dengan pelarut yang berbeda adalah untuk mengetahui pelarut yang dapat mengekstrak tanin dengan kadar tertinggi (Lailis, 2010).

Tulisan ini mendeskripsikan potensi senyawa tanin yang terdapat dalam daun mimba yang diduga mempunyai kemampuan sebagai antibakteri.

\section{Metode}

Alat-alat yang digunakan pada penelitian ini meliputi: alat-alat gelas (gelas kimia, gelas ukur, erlenmeyer, batang pengaduk, tabung reaksi, pipet tetes, buret, corong, labu ukur, neraca digital, kertas saring, penangas listrik, oven, termometer, kertas saring, botol semprot, spatula, statif dan klem dan penghancur elektronik penghalus.

Bahan yang digunakan dalam penelitian ini adalah daun mimba, $\mathrm{H}_{2} \mathrm{SO}_{4}$ pekat $5 \mathrm{M}$ (Merck), gelatin (Merck), $\mathrm{FeCl}_{3} 1 \%$ (Merck), indigocarmin (Merck), $\mathrm{KMnO}_{4} \quad 0,1 \mathrm{~N}$ (Merck), asam oksalat (Merck), etanol absolut 99\% dan air.

\section{Pembuatan larutan pereaksi}

0,6 gram indigocarmin dimasukkan ke dalam gelas ukur $100 \mathrm{~mL}$ dan dilarutkan dengan $50 \mathrm{~mL}$ aquades kemudian diaduk dan dipanaskan menggunakan penangas listrik. Setelah itu, didinginkan dan ditambahkan aquades hingga 100 $\mathrm{mL}$ lalu disaring.

\section{Larutan $\mathrm{KMnO}_{4} 0,1 \mathrm{~N}$}

0,31 gram $\mathrm{KMnO}_{4}$ ditimbang kemudian dimasukkan ke dalam gelas kimia $100 \mathrm{~mL}$ dan ditambahkan $100 \mathrm{~mL}$ aquades. Dididihkan menggunakan penangas listrik selama $1-15$ menit, kemudian disimpan selama satu malam. Setelah itu, disaring dan dimasukkan ke dalam labu ukur 250 mL. Selanjutnya diencerkan hingga mencapai 250 mL. Larutan $\mathrm{KMnO}_{4}$ distandarisasi terlebih dahulu sebelum dipakai.

\section{Standarisasi larutan $\mathrm{KMnO}_{4}$}

0,63 gram kristal asam oksalat ditimbang dan dimasukkan ke dalam gelas ukur $100 \mathrm{~mL}$ dan ditambahkan $75 \pm \mathrm{mL}$ aquades sambil diaduk. Larutan tadi dipindah ke dalam labu ukur $100 \mathrm{~mL}$ dan ditambahkan aquades hingga tanda batas. $25 \mathrm{ml}$ larutan asam oksalat ditambahkan $5 \mathrm{~mL} \mathrm{H}_{2} \mathrm{SO}_{4}$ pekat lalu dipanaskan hingga mencapai suhu $80{ }^{\circ} \mathrm{C}$. Selanjutnya dalam keadaan panas dititrasi dengan larutan $\mathrm{KMnO}_{4}$ sampai warna ungu dan sebelumnya tetesan larutan permanganat tidak hilang, lalu dicatat volume titrasi.
Mengulangi cara kerja (2 dan 3) sebanyak 2 kali dan masing-masing volume titrasi dicatat.

Normalitas larutan standar $\mathrm{KMnO}_{4}$ dihitung dengan menggunakan persamaan (Taty, 2009):

$$
\text { Normalitas } \mathrm{KMnO}_{4}=\frac{\mathrm{W}(\mathrm{mg}) / \mathrm{BM} \times 2 \times \mathrm{FP}}{\mathrm{V}(\mathrm{mL})}
$$

dimana W adalah berat kristal asam oklasat yang ditimbang (mg); BM adalah Berat molekul kristal asam oksalat; V adalah volume titrasi; FP adalah faktor pengenceran (25/100); dan 2 adalah elektron valensi asam oksalat.

Kadar air dihitung menggunakan rumus (Sudarmadji \& Haryono, 2003):

$$
\mathrm{K} \text { adar air }=\frac{a-\mathrm{b}}{a \times 100 \%}
$$

dimana a adalah berat awal sampel dan $\mathrm{b}$ adalah berat akhir sampel

Kadar tanin menggunakan persamaan dari Atanassova \& Christova (2009):

$$
\% \text { Tanin }=\frac{\left(\mathrm{V}-\mathrm{V}_{0}\right) \times 0,004157 \times \mathrm{FP}}{\text { sampel }(\mathrm{g})} \times 100 \%
$$

dimana $\mathrm{V}$ adalah volume titrasi tanin $(\mathrm{mL}) ; \mathrm{V}_{0}$ adalah volume blanko; $\mathrm{FP}$ adalah faktor pengenceran (250/25); dan $1 \mathrm{~mL} \mathrm{KMnO4} \mathrm{0,1} \mathrm{N}$ adalah setara 0,004157 gram tanin.

\section{Hasil dan Pembahasan}

Sampel daun mimba dalam penelitian ini terlebih dahulu dipisahkan daun dari tangkainya, lalu dicuci menggunakan air bersih dengan tujuan untuk menghilangkan pengotor seperti debu yang menempel pada daun. Selanjutnya dikeringkan di dalam oven dengan suhu berkisar $80{ }^{\circ} \mathrm{C}$ selama \pm 8 jam. Fungsi pengeringan ini adalah untuk mengurangi kadar air yang terkandung dalam sampel dan mencegah terjadinya perubahan kimia. Sampel kemudian dihaluskan dengan maksud untuk memperbesar luas permukaan sentuh sehingga mempermudah proses ektraksi berlangsung. Hal ini sesuai dengan prinsip laju reaksi bahwa semakin besar luas permukaan sentuh suatu partikel maka laju reaksi semakin cepat, sehingga kontak antara zat aktif dan pelarut semakin sering terjadi. Hasil yang diperoleh dari tahap ini adalah berupa serbuk berwarna hijau tua dan sampel telah siap dianalisis lebih lanjut untuk memperoleh hasil tanin secara uji kualitatif dan kuantitatif.

\section{Ekstraksi senyawa tanin dari daun mimba}

Ekstraksi adalah proses pemisahan suatu zat berdasarkan perbedaan kelarutannya terhadap dua cairan yang tidak saling larut (Mailoa, dkk., 2014). 
Prinsip ekstraksi adalah melarutkan senyawa polar dalam pelarut polar dan senyawa non polar dalam senyawa non polar (Lailis, 2010). Metode ekstraksi melibatkan pemisahan bagian aktif dari jaringan tanaman dengan menggunakan pelarut selektif. Selama ekstraksi, pelarut berdifusi ke dalam bahan tanaman padat dan melarutkan senyawa dengan polaritas yang sama (Tiwari, dkk., 2011).

Metode yang digunakan dalam penelitian ini adalah ekstraksi maserasi. Maserasi adalah salah satu metode pemisahan senyawa dengan cara perendaman menggunakan pelarut organik pada temperatur ruangan. Proses ekstraksi ini tidak dilakukan dengan metode soxhlet karena dikhawatirkan ada golongan senyawa tanin yang tidak tahan panas, selain itu senyawa tanin mudah teroksidasi pada suhu yang tinggi yaitu 98,89-101,67 . Proses maserasi sangat menguntungkan dalam isolasi senyawa bahan alam karena selain murah dan mudah dilakukan, dengan perendaman sampel tumbuhan akan terjadi pemecahan dinding dan membran sel akibat perbedaan tekanan antara di dalam dan di luar sel, sehingga metabolit sekunder yang ada dalam sitoplasma akan terlarut dalam pelarut (Ummah, 2010).

Menurut Wardani \& Leviana (2010) bahwa cairan penyari yang digunakan untuk proses ekstraksi berpengaruh terhadap rendemen ekstrak dan kadar tanin, dimana semakin besar kepolaran cairan penyari, semakin besar pula jumlah tanin yang dapat diperoleh dari proses ekstraksi. Suhu dan waktu sangat berperan penting dalam menentukan hasil tanin yang diperoleh dalam proses ekstraksi. Suhu ekstraksi dalam penelitian ini adalah $60{ }^{\circ} \mathrm{C}$ dan lama ekstraksi \pm 5 jam. Suhu yang paling baik dalam proses ekstraksi tanin adalah $70{ }^{\circ} \mathrm{C}$ dikarenakan jumlah tanin yang diperoleh pada suhu tersebut paling banyak. Hasil ekstraksi yang diperoleh selanjutnya disaring dengan tujuan untuk memisahkan antara filtrat dan residunya, filtrat yang didapat kemudian dipekatkan dengan cara pemanasan untuk menghilangkan pelarut yang digunakan dalam proses ekstraksi (Kusumaningsih, dkk., 2015).

Hasil ekstraksi menggunakan pelarut air berwarna coklat kemerahan dengan massa diperoleh 47,61 g. Nilai rendemen dari ekstrak tanin yang diperoleh pada penelitian ini adalah 95,22\%, hal ini diduga senyawa dalam daun mimba yang terekstrak dengan pelarut air memiliki kepolaran yang sesuai sehingga dapat menghasilkan rendemen paling tinggi. Rendemen ekstrak yang berbeda pada setiap perlakuan bergantung pada kemampuan masingmasing pelarut. Tanin merupakan senyawa polar maka akan larut baik dalam pelarut-pelarut yang bersifat polar, sedangkan hasil ekstraksi menggunakan pelarut etanol 96\% berwarna hijau kehitaman dengan massa diperoleh $27,3 \mathrm{~g}$ dan nilai rendemen dari ekstrak tanin adalah $54,6 \%$.

Uji fitokimia senyawa tanin pada penelitian ini yaitu dengan menambahkan ekstrak dengan larutan $\mathrm{FeCl}_{3}$ hasil positifnya akan terbentuk warna hijau kehitaman dan yang kedua adalah dengan menggunakan gelatin jika terbentuk endapan putih pada ekstrak maka senyawa tersebut mengandung tanin (Moelyono, 1996). Hasil uji fitokimia antara ekstrak daun mimba menggunakan pelarut air dengan $\mathrm{FeCl}_{3}$ dalam penelitian ini yakni berwarna coklat kemerahan. Hasil uji ini mengindikasikan bahwa ekstrak daun mimba menggunakan pelarut air mengandung senyawa tanin.

Berdasarkan hal tersebut maka dilakukan pengujian tanin pada ekstrak daun mimba dengan larutan gelatin dan hasil uji fitokimia menunjukkan adanya endapan berwarna putih. Dimungkinkan ekstrak daun mimba mengandung senyawa tanin. Penetapan kadar tanin dalam ekstrak daun mimba menggunakan metode Lowenthal-Procter (permanganometri). Metode ini melibatkan proses oksidasi-reduksi atau redoks. Pada penelitian ini digunakan larutan $\mathrm{KMnO}_{4}$ sebagai larutan standar karena termasuk oksidator kuat, umum digunakan, mudah diperoleh, dan tidak mahal (Ryanata, 2014). Prinsip dari metode ini adalah mengukur volume $\mathrm{KMnO}_{4}$ yang dibutuhkan dalam proses titrasi sampel sampai terjadi perubahan warna kuning keemasan.

Ekstrak tanin yang diperoleh sebelumnya dilarutkan dalam aquades lalu dipanaskan pada suhu 40-60 ${ }^{\circ} \mathrm{C}$ selama 30 menit dengan tujuan untuk mempercepat pelarutan, larutan sampel selanjutnya disaring untuk memisahkan antara filtrat dan residu. Filtrat yang diperoleh kemudian diencerkan hingga mencapai volume $250 \mathrm{~mL}$. Selanjutnya ke dalam 25 $\mathrm{mL}$ larutan sampel ditambahkan tetes demi tetes larutan indigocarmin dan dititrasi dengan larutan $\mathrm{KMnO}_{4}$ yang sebelumnya telah distandarisasi. Indigocarmin sendiri berfungsi sebagai indikator untuk mendeteksi terjadinya titik akhir titrasi. Warna larutan yang terbentuk sebelum titrasi adalah berwarna biru, selanjutnya titrasi dilakukan dengan ditambahkan sebanyak $1 \mathrm{~mL} \mathrm{KMnO}_{4}$ hingga warna berubah dari biru menjadi hijau. Titrasi dilakukan tetes demi tetes hingga warna hijau sebelumnya berubah menjadi warna kuning yang menandakan tercapainya titik akhir titrasi.

Kalium permanganat berperan sebagai oksidator yang akan mengoksidasi fenolat yang terkandung dalam sampel. Untuk $1 \mathrm{~mL} \mathrm{KMnO}_{4} 0,1$ $\mathrm{N}$ akan mengoksidasi tanin sebanyak 0,004157 gram (Atanassova \& Christova, 2009). Titrasi permanganometri dilakukan sebanyak 3 kali untuk mendapatkan hasil yang lebih akurat dan penetapan blanko juga dilakukan untuk mengetahui seberapa banyak $\mathrm{KMnO}_{4}$ yang bereaksi dengan indigocarmin. Hasil penelitian menunjukkan bahwa dari $50 \mathrm{~g}$ sampel ekstrak daun mimba menggunakan pelarut air mengandung senyawa tanin sebesar $0,55 \%$. Sedangkan ekstrak daun mimba menggunakan pelarut etanol $96 \%$ mengandung senyawa tanin $0,27 \%$.

\section{Kadar air}

Pada penelitian ini menganalisis kadar air dalam ekstrak daun mimba dengan menggunakan pelarut air dan etanol 96\%. Hasil analisis kadar air dalam ekstrak daun mimba dengan berat awal sampel 10 gram dan berat akhir 7,77 gram setelah proses 
pengovenan dan penimbangan, maka diperoleh persentase kadar air sebesar 22,3\%.

\section{Kadar tanin dalam ekstrak daun mimba}

Berdasarkan hasil ekstraksi dari daun mimba dengan pelarut air dan pelarut etanol 96\% diperoleh hasil kadar tanin sebagai berikut:

Tabel 1. Hasil penetapan kadar senyawa tanin pada daun mimba

\begin{tabular}{lllllll}
\hline Pelarut & $\begin{array}{l}\text { Sampel } \\
(\mathrm{gr})\end{array}$ & Filtrat & $\begin{array}{l}\text { Titran } \\
\mathrm{V}-\mathrm{V}_{0} \\
(\mathrm{~mL})\end{array}$ & $\begin{array}{l}\text { Massa } \\
\text { Tanin }\end{array}$ & $\begin{array}{l}\text { Kadar } \\
\text { Tanin }\end{array}$ & $\begin{array}{l}\text { Standar } \\
\text { Deviasi }\end{array}$ \\
\hline \multirow{2}{*}{ Air } & 50 & \multirow{2}{*}{$47,61 \mathrm{~g}$} & 0,2 & & $0,55 \%$ & \\
& & & 0,2 & 0,008314 & $0,55 \%$ & 0 \\
Etanol & & & 0,1 & & $0,55 \%$ & \\
$96 \%$ & 50 & \multirow{2}{*}{$27,3 \mathrm{~g}$} & 0,1 & 0,004157 & $0,27 \%$ & \\
& & & 0,1 & & $0,27 \%$ & \\
\hline
\end{tabular}

Persentasi kadar tanin dalam pelarut air lebih besar dibandingkan dalam pelarut etanol perbedaan ini disebabkan karena air lebih polar dibandingkan dengan etanol, sedangkan tanin juga bersifat polar sehingga pada proses ekstraksi tanin lebih banyak larut dalam air dibandingkan dalam etanol. Dengan kata lain pelarut memiliki peranan penting dalam proses ekstraksi.

\section{Kesimpulan}

Berdasarkan hasil penelitian tentang analisis kadar tanin dalam ekstrak air dan ekstrak etanol pada daun mimba (azadirachta indica A. Juss) menggunakan metode Lowenthal-Procter, maka dapat disimpulkan bahwa kadar tanin pada daun mimba (azadirachta indica A. Juss ) dengan ekstrak air adalah $0,55 \%$ dan kadar tanin daun mimba dengan ekstrak etanol 96\% adalah 0,27\%.

\section{Ucapan Terima Kasih}

Ucapan terimakasih penulis sampaikan kepada Tasrik laboran laboratorium Fakultas Keguruan dan Ilmu Pendidikan yang telah memberikan bimbingan dan masukan dalam menyelesaikan penelitian ini.

\section{Referensi}

Agus, F., dan Rahayu, S. (2004). Mimba (Azadirachta indica) dan manfaatnya. Bogor: World Agroforestry Centre.

Atanassova, M., \& Christova, V. (2009). Determination of tannins content by titrimetric method for comparison of different plant species. Journal of the University of Chemical Technology and Metallurgy, 44(4), 413-415.

Desinta, T. (2015). Penentuan jenis tanin secara kualitatif dan penetapan kadar tanin dari kulit buah rambutan (Nephelium lappaceum. L) secara permanganometri. Jurnal Ilmiah Mahasiswa Universitas Surabaya, 4(1), 1-10.

Harborne, J. B. (1987). Metode fitokimia. Bandung: Penerbit ITB.
Handayani, Wartono, N. A., Murti, M. W. A., \& Kurnia, R. (2012). Identifikasi dan uji aktivitas antibakteri fraksi teraktif daun mimba (Azadirachta indica A. juss). ALCHEMY Jurnal Penelitian Kimia, 8(1), 57-69.

Jayaraman, S., SenthilKumar, K., Ivakumar, R., Jagatheesh, K., \& Arunachalam, G. (2014). Evaluation of phytochemical and biological properties on strobilanthes ciliatus nees. $A n$ International Journal of Advances in Pharmaceutical Sciences, 5(1), 1821-1828.

Jesudoss, R. P. R., Vasanthi, N., \& Gayathri, P. (2014). Extraction and antifungal activity of tannin from tamarind husk. International Journal of Pharmacy and Bio Sciences, 5(2), 475483.

Kusumaningsih, T., Asrilya, N. J., Wulandari, S., Dewi Restu Tri Wardani, \& Fatikhin, K. (2015). Pengurangan kadar tanin pada ekstrak stevia rebaudiana dengan menggunakan karbon aktif. ALCHEMY Jurnal Penelitian Kimia, 11(1), 81-89.

Lailis, S. A. (2010). Isolasi dan identifikasi senyawa tanin dari daun belimbing wuluh (Avverhoa bilimbi L.). Malang: Universitas Islam Negeri Maulana Malik Ibrahim.

Mailoa, M. N., Mahendradatta, M., Laga, A., \& Djide, N. (2014). Effectiveness of tannins extract from leaf guava (Psidium guajava L) on the growth and damage of cell morphology escherichia coli. International Journal of Advance Research, 2(1), 908-914.

Malangngi, L. P., Paendong, J. J. E., \& Sangi, M. S. (2012). Penentuan kandungan tanin dan uji aktivitas antioksidan ekstrak biji buah alpukat (Persea americana mill. L). Jurnal MIPA UNSRAT Online, 1(1), 5-10. 
Moelyono, M. W. (1996). Panduan Praktikum Analisis Fitokimia. Laboratorium Farmakologi Jurusan Farmasi FMIPA. Bandung: Universitas Padjajaran.

Rishika, D., \& Sharma, R. (2012). An update of pharmacological activity of psidium guajava in the management of various disorders. International Journal of Pharceutical Science Research, 3(10), 3577-3584.

Ryanata, E. (2014). Penentuan jenis tanin dan penetapan kadar tanin dari kulit buah pisang masak (Musa paradisiaca L.) secara spektrofotometri dan permanganometri. Jurnal Ilmiah Mahasiswa Universitas Surabaya, 4(1), 116.

Sudarmadji, S., \& Haryono, B. S. (2003). Analisa bahan makanan dan pertanian. Yogyakarta: Liberty.

Taty, S. (2009). Analisis kadar tanin ekstrak air dan ekstrak etanol pada bji pinang sirih (Areca catechu L.). Jurnal Chemica, 10(1), 59-63.
Timothy, S. Y., Goji, S. Y., A. B., Mava, Y., \& Galadima, I. H. (2011). Antibacterial and phytochemical screening of the ethanolic leaf extract of azadirachta indica (Neem) (Meliceae). International Journal of Applied Biology and Pharmaceutical Technology, 2(3), 194-199.

Tiwari, P., Kumar, B., Kaur, M., Kaur, G., \& Kaur, H. (2011). Phytochemical screening and extraction: A review. Internationale Pharmaceutica Sciencia, 1(1), 98-106.

Ummah, M. K. (2010). Ekstraksi dan pengujian aktivitas antibakteri senyawa tanin pada daun belimbing wuluh (Avverhoa bilimbi L.). Skripsi Sarjana Fakultas Sains dan Teknologi. Malang: Universitas Islam Negeri Maulana Malik Ibrahim.

Wardani, A., \& Leviana, F. (2010). Pengaruh cairan penyari terhadap rendemen dan kadar tanin ekstrak daun jambu biji (Psidium guajava L.). Jurnal Farmasi Indonesia, 7(2), 57-61. 